\title{
Biodiversity and dynamics of the bacterial community of packaged king scallop (Pecten maximus) meat during cold storage
}

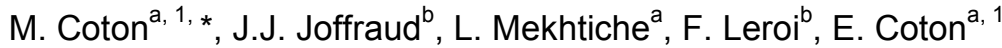

\author{
a ADRIA Normandie, Boulevard du 13 Juin 1944, 14310 Villers-Bocage, France \\ b IFREMER, Laboratoire Science et Technologie de la Biomasse Marine, Nantes, Rue de I'lle d'Yeu, BP 21105, \\ 44311 Nantes Cedex 03, France \\ ${ }^{1}$ Present address: Université de Brest EA3882, Laboratoire Universitaire de Biodiversité et Ecologie Microbienne \\ (LUBEM-EA3882), SFR ScInBioS, ESIAB, Technopôle Brest-Iroise, 29280 Plouzané, France.
}

*: Corresponding author: Monika Coton, Tel.: +33290915100 ; fax: +33291915101; email address : monika.coton@univ-brest.fr

\begin{abstract}
:
The microbial biodiversity and dynamics of king scallops meat and coral during cold storage (cold chain rupture: $1 / 3$ storage time at $4^{\circ} \mathrm{C}$ followed by $2 / 3$ at $8{ }^{\circ} \mathrm{C}$ ), was assessed by combining culturedependant and -independent methods. Products were packaged as follows: aerobic, vacuum packed and 3 different $\mathrm{CO}_{2} / \mathrm{N}_{2}$ modified atmospheres and the impact of these conditions on the microbial communities was assessed. Results indicated that under air (current packaging condition), the dominant species corresponded to Brochothrix thermosphacta, Pseudomonas spp. and Shewanella spp. These species have regularly been associated in the literature with food (especially seafood), and product spoilage. Moellerella wisconsensis was the only species detected on VRBG medium, however, its impact on the food product is unclear. Packaging conditions influenced the ecosystem equilibrium and biodiversity. Except for day 8, the lowest counts for all studied flora were observed for modified atmosphere packaging (MAP) containing $>80 \% \mathrm{CO}_{2}$. Moreover, in these conditions, higher biodiversity by Temporal Temperature Gradient Gel Electrophoresis (TTGE) and the non-detection of specific flora (i.e. Pseudoalteromonas haloplanktis) were observed. At day 8, scallops packaged using these conditions were still acceptable from a sensorial point of view (odour), although the initial load of the king scallop was high (total psychrotrophic flora reached 5.5 log CFU/g).
\end{abstract}

\section{Highlights}

High microbial biodiversity associated with king scallops during storage (at least 26 species). Impact of MAP on flora equilibrium especially at high $\mathrm{CO}_{2}$ concentrations. At day 8, scallops packaged with high $\mathrm{CO}_{2}$ concentrations were still acceptable from a sensorial point of view.

Keywords: King scallop ; Microbial biodiversity ; Modified atmosphere packaging (MAP) ; TTGE 


\section{Introduction}

The king scallop Pecten maximus is a valuable bivalve mollusc as it is a highly appreciated food product, especially in France (“coquilles Saint-Jacques”). France produces around 25000 tons of king scallops per year (FAO, 2006), a significant portion originate from the Normandy region. A large quantity of scallops is also imported to France and mainly originates from Scotland and North America (Pecten maximus and Placopecten magellanicus, respectively). In the context of new food consumption habits, in particular, ready-to-eat foods, a larger proportion of this bivalve mollusc production is sold shelled. King scallop meat is sold either frozen or fresh. As for other seafood products, shelf-life during cold storage is limited; thus, the study of alternative packaging or storage conditions is important.

Like other seafood products, scallop quality during packaging and storage is associated with biochemical and sensorial changes that are mainly affected by storage temperature (Ehira and Uchiyama, 1987; Kawashima and Yamanaka, 1992) and the development of microbial flora that can lead to spoilage (Ocaño-Higuera et al., 2006). Several methods have been used to evaluate the freshness of fish and shellfish. These methods are based on measuring chemical, physical and microbiological changes (Luong et al., 1991; Ohashi, 1991; Olafsdottir et al., 1997). The main indices used in relation to fish spoilage (Botta, 1995; Hebbard et al., 1982) correspond to trimethylamine nitrogen (TMA) and total volatile basic nitrogen (TVBN), as well as sensory changes; however, there is very limited data based on the changes observed during mollusc's spoilage and especially king scallops. Indeed, studies have rather been carried out on alterations of closely related species including sea scallops (Placopecten magellanicus) (Hilts and Dyer, 1970), queen scallops (Chlamys opercularis) (Thomson et al., 1974), yesso scallops (Patinopecten yessoensis) (Kawashima and Yamanaka, 1992) and lion-paw scallops (Nodipecten subnodosus) (Ocaño-Higuera et al., 2006) or have been based on the characterization of bacterial communities during the early 
life stages of scallops that may have an impact on the survival of bivalve larvae (Lane et al., 1985; Nicolas et al., 1996; Sandaa et al., 2003; Torkildesen et al., 2005).

Studies based on the impact of packaging conditions on bivalve mollusc spoilage during cold storage are rare. Ruiz-Capillas et al. (2001) compared the biochemical and sensory changes of frozen king scallops that were thawed and stored at $4^{\circ} \mathrm{C}$ in melting ice to samples wrapped in aluminium foil and cling film. Only few differences were observed between aluminium foil and cling film while the levels TMA and TVBN were low due to the leaching effect of the ice meltwater. Kimura et al. (2000) showed that storage at $5^{\circ} \mathrm{C}$ of scallop adductor muscle packaged under air or various $\mathrm{O}_{2}$ and $\mathrm{CO}_{2}$ atmospheres ranging from 20 to $40 \%$ had an impact on the bacteria found in the samples (inhibition from $20 \% \mathrm{CO}_{2}$ ) and that $100 \% \mathrm{O}_{2}$ allowed to prolong the shelf life by nearly two days in comparison to aerobic conditions.

Finally, the microflora associated with king scallops and their respective spoilage potential as well as the impact of packaging on the microbial diversity is not well documented. Thomson et al. (1974) indicated that the spoilage flora of the queen scallop (Chlamys opercularis) was similar to spoilage flora found in fish. While Llanos et al. (2002) showed that in the Peruvian scallop (Argopecten purpuratus), the initial flora was associated with culture conditions, farming localization and the feed used. Moreover, this flora would have a direct impact on spoilage. Bremner and Statham (1983) showed that Vibrio spp. were the dominant flora and persisted in vacuum packed Pecten alba scallops.

This study aimed at evaluating the microbial diversity of French king scallops meat and coral during cold storage and the impact of various packaging conditions on the bacterial ecosystem. The different modified atmosphere conditions were selected to test for their potential inhibiting properties towards spoilage bacteria at temperatures encountered by the consumer during food storage. Indeed, practical industrial studies tend to suggest that TVBN 
content is lower in $\mathrm{CO}_{2}$ rich environments for some seafood products. Both microbiological and molecular tools were used to follow and identify the bacterial communities during cold storage. To our knowledge, this is the first study on the bacterial community of king scallops using microbial and molecular tools.

\section{Materials and Methods}

\subsection{Sample preparation and bacterial numerations}

King scallops (Pecten maximus) harvested in the Basse-Normandie region were obtained just after shelling (meat and coral) on ice. They were then placed into trays (6 King scallop meats with coral per tray) and packaged under different conditions using a Multivac Galaxy TS 355 semi-automatic tray sealer (Multivac, France) with $150 \mu \mathrm{m}$ thick polyethylene film. A total of 5 different modified atmosphere packaging conditions were tested for each sampling date (day D1, D4, D6 and D8) and corresponded to air conditions, vacuum packed and three different modified atmospheres $\left(50 \% \mathrm{CO}_{2} / 50 \% \mathrm{~N}_{2}, 80 \% \mathrm{CO}_{2} / 20 \% \mathrm{~N}_{2}, 100 \%\right.$ $\mathrm{CO}_{2}$ ). A 3:1 ratio of modified atmosphere to scallops was obtained in the sealed trays. The different modified atmosphere conditions were selected to test for their potential inhibiting properties towards spoilage bacteria at temperatures encountered by the consumer during food storage.

A cold chain rupture, $1 / 3$ storage time at $4^{\circ} \mathrm{C}$ and $2 / 3$ at $8^{\circ} \mathrm{C}$, was applied to each sample to mimic conditions encountered by the consumer during cold storage according to the guidelines given for best before date determinations (Norme NF V01-003). Microbial sampling was performed in triplicate. For each sampling date and packaging condition, the 6 King scallop meats per tray were separated into 3 samples (2 meats and coral) to obtain 3 sample repetitions. Then, for each repetition, $2.5 \mathrm{~g}$ of each meat and $2.5 \mathrm{~g}$ of each coral, 
corresponding to $10 \mathrm{~g}$ in total per repetition, were placed in a sterile stomacher bag and homogenized for $2 \mathrm{~min}$ in $90 \mathrm{ml}$ tryptone salt buffer using a stomacher (AES laboratories, France). In order to numerate total aerobic flora, homogenates were serially diluted and plated on modified Long and Hammer's medium (van Spreekens, 1974), then, incubated for 5 days at $15^{\circ} \mathrm{C}$. For enterobacteria, serial dilutions were plated onto Violet Red Bile Glucose (VRBG) agar (AES, France) and incubated for $48 \mathrm{~h}$ at $30^{\circ} \mathrm{C}$. Pseudomonas spp., were plated and enumerated on Cephalosporine Fucidine Cetrimide (CFC) medium (AES, France), lactic acid bacteria (LAB) on De Man Rogosa Sharpe (MRS, pH 6.4) (AES, France), Brochothrix thermosphacta colonies were enumerated on Streptomycin Thallous Acetate Actidione (STAA) agar (Oxoid, France) and $\mathrm{H}_{2} \mathrm{~S}$ producing bacteria on Iron Agar (IA) (tryptone $20 \mathrm{~g} / \mathrm{L}$, $\mathrm{NaCl} 5 \mathrm{~g} / \mathrm{L}$, beef extract $3 \mathrm{~g} / \mathrm{L}$, yeast extract $3 \mathrm{~g} / \mathrm{L}$, ferric citrate $0.3 \mathrm{~g} / \mathrm{L}$, sodium thiosulfate $0.3 \mathrm{~g} / \mathrm{L}$ and agar $12 \mathrm{~g} / \mathrm{L}$ ). CFC, MRS, STAA and IA plates were incubated at $25^{\circ} \mathrm{C}$ for $48 \mathrm{~h}, 5$ days, $48 \mathrm{~h}$ and $72 \mathrm{~h}$, respectively. For each Petri dish containing $\mathrm{n}<300$ and at each sampling date, the square root of the total number of colonies were selected according to morphological, microscopic and biochemical aspects (sampling was performed according to morphotypes, Gram-staining, catalase and oxidase testing to ensure proper species representation). Overall, 311 isolates were selected for further study using molecular tools. In parallel, the king scallop homogenates used for microbiological analyses were filtered on Minisart $5 \mu \mathrm{m}$ filters (Sartorius, France) and kept frozen at $-20^{\circ} \mathrm{C}$ for latter use in Temporal Temperature Gel Electrophoresis (TTGE) analyses. Indeed, previous studies performed by our laboratory have shown that there is no impact on TTGE results after freezing samples at $20^{\circ} \mathrm{C}$ (data not shown).

\subsection{Culture conditions}


All representative strains were cultivated in tryptic soy broth (TSB, AES,) supplemented with $2.5 \mathrm{~g} / 1$ yeast extract (TSBYE) except LAB which were cultivated in MRS broth (AES, France). All isolates, except LAB, were incubated at $25^{\circ} \mathrm{C}$ for $24 \mathrm{~h}$ under agitation. $\mathrm{LAB}$ were incubated at $30^{\circ} \mathrm{C}$ for $24-48 \mathrm{~h}$. Strains were finally conserved in cryotubes with $30 \% \mathrm{v} / \mathrm{v}$ glycerol at $-80^{\circ} \mathrm{C}$.

\subsection{Isolate M13-PCR grouping and identification}

\subsubsection{Preparation of template DNA}

DNA was extracted from bacterial cultures grown to stationary phase using $1 \mathrm{ml}$ of culture with the NucleoSpin Tissue Kit (Macherey Nagel, France) according to the manufacturer's instructions for bacteria. Purified DNA samples were stored at $-20^{\circ} \mathrm{C}$.

\subsubsection{PCR amplification}

For strain grouping, genetic profiles were generated for each isolate as described by Guinebretière and Nguyen-The (2003). Briefly, $1 \mu$ purified DNA ( $\sim 50 \mathrm{ng}$ ) was used for each reaction in the presence of $2.0 \mu \mathrm{M}$ M13 primer (5'-GAGGGTGGCGGCTCT-3'), $400 \mu \mathrm{M}$ dNTP in the presence of $1.25 \mathrm{U}$ Taq polymerase (5 PRIME, Germany). Amplification conditions were as follows: $95^{\circ} \mathrm{C} 5 \mathrm{~min}, 45$ cycles of $95^{\circ} \mathrm{C} 1 \mathrm{~min}, 36^{\circ} \mathrm{C} 1 \mathrm{~min}, 72^{\circ} \mathrm{C} 4 \mathrm{~min}$. For strain identification, amplification and sequencing of a 1533bp 16S rRNA gene fragment was carried out using the universal primers BSF8 and BSR1541 (Edwards et al., $1989)$ in the presence of $\sim 50 \mathrm{ng}$ DNA, $0.2 \mu \mathrm{M}$ each primer, $1.5 \mathrm{mM} \mathrm{MgCl}_{2}, 200 \mu \mathrm{M}$ dNTPs and $1 \mathrm{U} \mathrm{Taq}$ polymerase (Invitrogen, France). Amplification conditions were $94^{\circ} \mathrm{C}$ for $5 \mathrm{~min}$, 30 cycles of $94^{\circ} \mathrm{C}$ for $45 \mathrm{sec}, 59.5^{\circ} \mathrm{C}$ for $45 \mathrm{sec}, 72^{\circ} \mathrm{C}$ for 2 min with a final extension at $72^{\circ} \mathrm{C}$ for 5 min. All PCR were performed in a Master Gradient thermocycler (Eppendorf, France). 


\subsubsection{Gel electrophoresis}

Aliquots (9 $\mu \mathrm{l}$ for M13 PCR products and $18 \mu$ l for $16 \mathrm{~S}$ rDNA fragments) of each PCR sample were analyzed using 1.2\% (M13-RAPD experiments) or $0.8 \%$ (16S rDNA experiments) (wt/vol) agarose gels (Invitrogen, France) in $1 \mathrm{X}$ TBE buffer at $130 \mathrm{~V}$ for $50 \mathrm{~min}$ then visualized with ethidium bromide staining using a GelDoc2000 (BioRad, France).

\subsubsection{Genetic profile clustering and sequence analysis}

M13-PCR genetic banding patterns were analyzed using Quantity One software (BioRad, France) and BioNumerics fingerprinting software version 5.1 (Applied Maths, Belgium). For sequencing, 16S rDNA amplicons (1533bp) were purified using the GenElute PCR purification kit (Sigma, France) and sent to Eurofins MWG Operon for sequencing (Abersberg, Germany). Alignments were performed using the ClustalX program or Bionumerics software and sequence similarity was determined using BLAST (Altschul et al. 1990) in the GenBank database.

\subsection{TTGE gel electrophoresis}

\subsubsection{Total bacterial DNA extraction.}

Filtrates obtained from each sampling homogenate were thawed overnight at $4^{\circ} \mathrm{C}$, and then $10 \mathrm{ml}$ of homogenised filtrate were filtered on a Nucleospin Plant column (MachereyNagel, France) by centrifugation at $8500 \mathrm{rpm}$ for $10 \mathrm{~min}$. The pellet was resuspended in 400 $\mu 1$ of lysis solution (Tris-HCL20 mM, pH 8.0, EDTA 2 mM, Triton X-100 1.2 \%, lysozyme $20 \mathrm{mg} / \mathrm{ml}$, mutanolysin $11.6 \mathrm{U})$, then transferred in $2 \mathrm{ml}$ microtubes and incubated at $37^{\circ} \mathrm{C}$ for $1 \mathrm{~h}$. This enzymatic lysis was followed by a mechanical lysis performed by addition of $0.3 \mathrm{~g}$ of glass beads (150-200 $\mu \mathrm{m}$ diameters) and agitation for 2 cycles of 2 minutes at $30 \mathrm{~Hz}$ in a MM 200 mixer mill (Retsh, Germany). Proteins were digested by proteinase K (20 mg/ml) in 
$200 \mu \mathrm{l}$ of DNeasy blood and tissue kit AL buffer (Qiagen, France) and incubation performed at $56^{\circ} \mathrm{C}$ for $30 \mathrm{~min}$. Glass beads were pelleted by centrifugation at $10000 \mathrm{rpm}$ for $3 \mathrm{~min}$ and the supernatant was then transferred in a $2 \mathrm{ml}$ microtube for DNA precipitation by addition of $200 \mu 1$ of cold absolute ethanol at $-20{ }^{\circ} \mathrm{C}$. Total DNA was finally purified using the DNeasy blood and tissue kit (Qiagen, France) according to the manufacturer's instructions.

\subsubsection{PCR amplification.}

The 16S rRNA gene V3 region (194 bp) was amplified using the following primers: V3P2 (5'-ATTACCGCGGCTGCTGG-3') and V3P3 with GC clamp (5'CGCCCGCCGCGCGCGGCGGGCGGGGCGGGGGCAGGGGGGCCTACGGGAGGCAG CAG-3') (Jaffrès et al., 2009). Amplification was performed in $50 \mu$ final volume with $40 \mu 1$ of PCR mix containing in final concentration: dNTP $800 \mu \mathrm{M}$ (Interchim, France), 1 X Taq buffer (Tris-HCL $10 \mathrm{mM}$ [pH 9.0], KCL $50 \mathrm{mM}, \mathrm{MgCl}_{2} 1.5 \mathrm{mM}$, Triton X-100 0.1\% and BSA $0.2 \mathrm{mg} / \mathrm{ml}$ ), $2.5 \mathrm{U}$ of Taq DNA polymerase (MP Biomedicals, France), $1 \mu \mathrm{M}$ of each primer and $10 \mu 1$ of extracted total DNA. PCR amplification was performed in a PTC-100 thermocycler (MJ Research Inc, USA) with the following conditions: $94^{\circ} \mathrm{C}$ for $5 \mathrm{~min}, 40$ cycles of $94^{\circ} \mathrm{C}$ for $30 \mathrm{sec}, 62^{\circ} \mathrm{C}$ for $30 \mathrm{sec}, 72^{\circ} \mathrm{C}$ for $1 \mathrm{~min}$. A final extension at $72^{\circ} \mathrm{C}$ for 30 min was performed. The quality and size of the amplicons were evaluated on agarose gel $1 \%$ (MP Biomedicals, France) with a 100 bp ladder (Fermentas Life Science, France).

\subsubsection{TTGE analysis}

Amplified fragments were separated using the DCode Universal Mutation Detection System (BioRad, France). Polyacrylamide gels (16 cm x $16 \mathrm{~cm}, 1 \mathrm{~mm}$ thickness) consisted of two layers including resolving and stacking gels. Resolving gels were prepared with $9.5 \%$ (w/v) of an acrylamide solution (acrylamide-bisacrylamide, $37.5: 1$ ) and urea $8 \mathrm{M}$ (final 
concentration) in $1.25 \mathrm{X}$ Tris base Acetic acid EDTA (TAE) buffer obtained from a $50 \mathrm{X}$ TAE buffer (Tris base $2 \mathrm{M}$, glacial acetic acid $1 \mathrm{M}$, EDTA $50 \mathrm{mM}$ ). Stacking gels were prepared without urea with $16 \%(\mathrm{w} / \mathrm{v})$ of acrylamide solution (acrylamide-bisacrylamide, 37.5:1) in $1.25 \mathrm{X}$ TAE buffer. Acrylamide gel polymerisation was initiated by addition of ammonium persulfate $(10 \%)$ and $\mathrm{N}, \mathrm{N}, \mathrm{N}$, , N'-tetramethylethylenediamine (TEMED) just before pouring into the vertical glass plate sandwich. After polymerisation, the gels were stored overnight at $4^{\circ} \mathrm{C}$. Electrophoresis was run in $1.25 \mathrm{X}$ TAE buffer. Before loading the PCR products, the wells were rinsed with $1.25 \mathrm{X}$ TAE buffer. Thirty $\mu$ l of amplified fragments with $1 \mathrm{X}$ of loading buffer (1:1) were then loaded in the wells. Electrophoresis were performed at $50 \mathrm{~V}$ for $12 \mathrm{~h} 30$ with a temperature gradient ranging from $65^{\circ} \mathrm{C}$ to $70^{\circ} \mathrm{C}\left(0.4^{\circ} \mathrm{C} / \mathrm{h} \mathrm{ramp}\right)$ under stirring with a magnetic stirrer to mix the buffer and improve the temperature gradient homogeneity. After electrophoresis, gels were rinsed for 20 min in MilliQ water (Millipore, France); stained for $30 \mathrm{~min}$ in $300 \mathrm{ml}$ of $3 \mathrm{X}$ GelRed staining solution (Fluoprobes, Interchim, France) in water containing $\mathrm{NaCl} 0.1 \mathrm{M}$ and then rinsed in MilliQ water. Finally, gels were photographed by UV illumination using an ImageMaster VDS-CL imaging system (Amersham Pharmacia Biotech, France).

TTGE gels were standardized by using a V3 identification ladder made up of ten reference species resulting in ten bands well spread over the track length. TTGE banding patterns were analysed using BioNumerics fingerprinting software version 5.1 (Applied Maths, Belgium).

\subsection{Total volatile basic nitrogen (TVBN) and trimethylamine (TMA) content}

TVBN and TMA content were determined in this study using the Conway method as an index of freshness quality for the scallop samples at each sampling date (Conway and Byrne, 1936). Briefly, $100 \mathrm{~g}$ sample were homgenized then TVBN were extracted with 
trichloroacetic acid (TCA). Mixtures were filtered using Whatman filter paper and the filtrate was used for analysis. For TMA determination, a 40\% formaldehyde solution was added to the solution to fix the ammonia present in the sample. TVBN and TMA were released after addition of a $112 \%$ potassium carbonate solution and diffused into a $1 \%$ boric acid solution. Samples were then titrated by $0.01 \mathrm{~N} \mathrm{HCl}$ until a rose colour appeared and TVBN and TMA contents were determined. TVBN was expressed as the quantity of $\mathrm{NH}_{3}$ in the homogenised product using the following formula: [ $\mathrm{V}$ in $\mathrm{ml}$ hydrochloric acid $\mathrm{X} 0.17$ (mass in $\mathrm{g}$ homogenised product + mass in $\mathrm{g}$ water + mass in g 20\% TCA) X 100] / [1 X TCA density X ml]. TMA was expressed as mg nitrogen per $100 \mathrm{~g}$ product using the formula: [V in $\mathrm{ml}$ hydrochloric acid X 0.14 (mass in g homogenised product + mass in g water + mass in g 20\% TCA) X 100] / [1 X TCA density X ml].

\section{6} different sampling dates (D1, D4, D6, D8) with a trained panel of 6-8 judges. To do so, different factors were considered and included visual aspect, odour and texture/firmness for both raw and cooked scallops and corals. A list of descriptors was made and grades were given based on 4 major sensorial criteria (odour, scallop aroma, coral aroma, and presence of spots) in order to judge scallop quality and freshness. For cooked scallops, samples were placed for 1 minute in a microwave at $750 \mathrm{~W}$. Before each session, samples were placed in airtight containers prior to disposing them onto tasting plates.

\section{Results}

\subsection{Culture-dependent community dynamics}


Microbiological analyses targeting various bacterial floras (total psychrotrophic flora, B. thermosphacta, pseudomonads, enterobacteria, lactic acid bacteria and $\mathrm{H}_{2} \mathrm{~S}$-producing bacteria) were performed at each sampling day (D1, D4, D6 and D8) and for each packaging condition (aerobic, vacuum, $50 \% \mathrm{CO}_{2} / 50 \% \mathrm{~N}_{2}, 80 \% \mathrm{CO}_{2} / 20 \% \mathrm{~N}_{2}$ and $100 \% \mathrm{CO}_{2}$ ) by triplicate analyses (Figure 1).

The results obtained on Long \& Hammer medium indicated that total psychrotrophic flora counts were high during the entire storage period and under all packaging conditions. Counts ranged from $5.5 \log$ CFU/g at day D1 and almost reached $8 \log$ CFU/g at day D8. Noteworthy, a difference of about $1 \log$ was observed at day D4 between aerobic and vacuum packed conditions $(\sim 7 \mathrm{logs} \mathrm{CFU} / \mathrm{g})$ versus the 3 different $\mathrm{CO}_{2}$ rich modified atmosphere conditions ( 6 logs CFU/g) (Figure 1A).

For VRBG medium targeting enterobacteria (Figure 1B), counts were the lowest with $1 \log$ CFU/g at day D1 and a maximum of about $4.5 \log$ CFU/g at day D8 under aerobic conditions. While the largest differences were observed at day D6, with vacuum packaging allowing for faster growth and $80 \% \mathrm{CO}_{2}$ allowing for the slowest growth, at day D8 the maximum counts observed were relatively close to each other (ranging from 3.9 to $4.5 \mathrm{log}$ $\mathrm{CFU} / \mathrm{g})$.

Concerning STAA medium numerations, results indicated that the packaging conditions had a limited but statistically significant effect. Indeed, although growth curves were parallel, they showed, at day D8, that aerobic packaging conditions allowed for the highest growth (6.9 log CFU/g) followed by vacuum packed samples and $50 \% \mathrm{CO}_{2} / 50 \% \mathrm{~N}_{2}$ modified atmosphere conditions $(\sim 6.5 \log \mathrm{CFU} / \mathrm{g})$. Packaging conditions with more than $80 \% \mathrm{CO}_{2}$ presented the lowest counts $(\leq 6 \log \mathrm{CFU} / \mathrm{g})$ (Figure 1C).

For lactic acid bacteria numerated on MRS medium (Figure 1D), growth curves were parallel except for $50 \% \mathrm{CO}_{2} / 50 \% \mathrm{~N}_{2}$ that reached a plateau at day $6(\sim 7.0 \log \mathrm{CFU} / \mathrm{g})$. At day 
D8, the highest growth was observed for air packaged scallops while slowest growth rates were observed for modified atmosphere conditions with over $80 \% \mathrm{CO}_{2}(\sim 6.0 \log \mathrm{CFU} / \mathrm{g})$. Concerning CFC medium targeting pseudomonads, the obtained results showed the highest differences (Figure 1E). While packaging under aerobic conditions allowed for the growth of Pseudomonas spp. up to $6.5 \mathrm{log} \mathrm{CFU} / \mathrm{g}$; the other packaging conditions had an impact on this flora with almost no growth observed for vacuum packed samples or in the presence of $\mathrm{CO}_{2}$.

Finally, $\mathrm{H}_{2} \mathrm{~S}$-producing bacteria were numerated on IA medium and appeared with a black halo. At day D8, significant differences were found as highest counts $(\sim 6.2 \log \mathrm{CFU} / \mathrm{g})$ were observed for the air packaged scallops while lowest counts corresponded to all the other conditions $(<5.0 \log \mathrm{CFU} / \mathrm{g})($ Figure $1 \mathrm{~F})$. However, at day D6, modified atmosphere conditions with $100 \% \mathrm{CO} 2$ showed the lowest counts.

Overall, highest microbial flora counts were observed for air and in some cases vacuum packed and $50 \% \mathrm{CO}_{2} / 50 \% \mathrm{~N}_{2}$ packaged scallops during conservation; these results were in agreement with the highest levels of TVBN and TMA detected under these packaging conditions (Table 2). Moreover, sensory evaluation data also showed that air packaged, vacuum packed and $50 \% \mathrm{CO}_{2} / 50 \% \mathrm{~N}_{2}$ modified atmosphere samples were significantly different and considered unacceptable after day D6 while those for $80 \% \mathrm{CO}_{2} / 20 \% \mathrm{~N}_{2}$ and $100 \% \mathrm{CO}_{2}$ modified atmosphere samples were inferior to the sensory evaluation acceptability limits (data not shown) These results allowed us to determine TVBN and TMA sensorial evaluation acceptability limits of $<30 \mathrm{mg} \mathrm{N} / 100 \mathrm{~g}$ and $<10 \mathrm{mg} \mathrm{N} / 100 \mathrm{~g}$ for Pecten maximus scallops, respectively.

\subsection{M13-PCR typing and inter-and intra-species biodiversity}


Genetic diversity of 311 representative isolates originating from the various media was assessed by obtaining genetic profiles using the coliphage M13 sequence-based PCR (M13-PCR) method (Henderson et al. 1994; Guinebretière and Nguyen-The 2003). The profiles generated for the 311 strains were then integrated and analyzed in a Bionumerics database (Figure 2 presents an example of profiles generated for isolates at day 8 from the various media). The repeatability and reproducibility of all experiments was also evaluated by using 2 control strains (laboratory control strains) in all M13-PCR experiments. Overall, a high level of M13-PCR genetic profile diversity was observed with at least 104 different profile types, of which 57 contained from 2 to 20 isolates (data not shown).

Strain identifications at the species level were then carried out, via sequencing of a 1533 bp 16S rRNA gene fragment, on 58 representative isolates (isolates within dominant M13 profile type clusters or unique isolates). Overall, high species diversity was observed with at least 26 different species (Table 1). The non-selective Long \& Hammer medium showed the presence of various genera and species including numerous Gram-positive and Gram-negative bacteria. Overall, on this medium, the dominant genera corresponded to Pseudomonas, Brochothrix and Shewanella $(20.2 \%, 15.9 \%$ and $14.9 \%$ of all LH isolates, respectively). A certain level of species biodiversity was also observed on CFC medium; dominant species corresponded to pseudomonads (46.9\% of all CFC isolates) (Pseudomonas sp., P. fluorescens, P. jensenii, P. syringae and P. fragi) followed by Shewanella spp. (17.2\% of all CFC isolates) (S. baltica S. putrefaciens and S. frigidimarina) and to a lesser extent Pseudoalteromonas haloplanktis and Morganella morganii. For Iron Agar, Shewanella spp. (in particular, S. baltica and S. putrefaciens) were dominant represented $61.7 \%$ of all IA isolates. On MRS medium, Carnobacterium maltaromaticum and Actinomyces radicidentis were observed (data not shown). Moellerella wisconsensis was the only species identified on VRBG medium; while bacteria growing on the STAA medium almost only corresponded to 
B. thermosphacta. Low intra-species diversity was observed using these tools for strains belonging to the Moellerella wisconsensis and S. putrefaciens species (only 1 or 2 genetic profile clusters for each species). On the contrary, B. thermosphacta and S. baltica presented high infraspecific diversity and were distributed on the generated dendrogram in 5 different groups for both species (data not shown).

\subsection{Incidence of storage duration and packaging conditions}

Bacterial counts combined with species identification data allowed to study the impact of the storage period and packaging conditions on king scallop microbial ecosystem equilibrium. Concerning the storage duration (all packaging conditions considered), some variations of the represented species from day D1 to day D8 were observed except in the case of Pseudomonas spp. that were dominant at day 1 and remained stable during the following days (except under air). In particular, B. thermosphacta showed highest prevalence in all conditions followed by Shewanella spp. and Moellerella wisconsensis (except at day D1) (Table 3).

Regarding the impact of packaging conditions on bacterial genus distribution (all storage days considered), the analysis indicated that the dominant genera Pseudomonas, Brochothrix, Shewanella and to a lesser extent Staphylcoccus spp. were present in every packaging condition although some differences in the respective ratios were observed (Table 3). Mainly, bacteria growing on CFC and IA (in particular, Pseudomonas and Shewanella spp.) were affected by all conditions eliminating oxygen from the packaging atmosphere. $B$. thermosphacta and C. maltaromaticum were slightly affected by the presence of $\mathrm{CO}_{2}$ with an approximately $1 \log$ unit reduction in " $100 \% \mathrm{CO}_{2}$ " MAP as observed by STAA and MRS media counts, respectively, while Moellerella wisconsensis showed lower differences. The obtained result also indicated that the packaging conditions could have a deeper impact on 
specific microorganisms. For example, the Pseudoalteromonas genus, represented in this study by the Pseudoalteromonas haloplanktis species, was not found in " $80 \% \mathrm{CO}_{2} / 20 \% \mathrm{~N}_{2}$ " and " $100 \% \mathrm{CO}_{2}$ " MAP conditions. This result suggested that this species is sensitive to high $\mathrm{CO}_{2}$ concentrations rather than to anaerobic conditions as it was detected in the "vacuum packed" and " $50 \% \mathrm{CO}_{2} / 50 \% \mathrm{~N}_{2}$ " packaging conditions.

\subsection{Culture-independent community dynamics}

In parallel, the TTGE molecular method was used in order to contribute to the study of the biodiversity as well as the dynamics of the king scallop meat ecosystem during storage. The obtained TTGE profiles indicated that the repeats were highly similar (data not shown); therefore, only one representative TTGE profile was selected for further analysis. The corresponding 17 selected profiles were analyzed and compared using the Bionumerics software which generated a proximity dendrogram (Figure 3).

After day D6, the bacterial flora seemed to be stable in each packaging condition and patterns at day D6 and day D8 were similar. These patterns have been clustered according to the different packaging atmospheres showing their respective effect on the microbiota composition. The profiles obtained at day D4, although close to those from day D6 and day D8, did not group as closely suggesting that at this sampling date the flora ecosystem was still evolving.

The effect of each packaging condition on the evolution of the TTGE profiles during the storage period was also analyzed. For the king scallop meats packaged under aerobic or vacuum packed conditions, the profiles obtained between days D4 and D8 were similar (except for day D6 under vacuum packaging). The largest modification of the microbial ecosystem composition seemed to appear between the first and the fourth day. 
For the products packaged in the presence of $\mathrm{CO}_{2}$, the profiles evolved between days D1, D4 and D6. From day D6, the ecosystems seemed to be stabilized. Moreover, on these products, a larger number of bands could reflect a higher diversity of the king scallop microbiota in these samples, however, some species may present multiple bands.

By comparing the profiles obtained from the different products to the profiles obtained from pure strains representative of the biodiversity as observed by M13-PCR typing, band assignment was performed although some pure strains exhibited several bands in their TTGE profiles (data not shown). The band associated with the dominating genus on culture media (i.e. Pseudomonas) was not found in the product profiles and sporadically present for Brochothrix and Shewanella putrefaciens.

\section{Discussion}

The first part of this work consisted in studying the main groups of flora associated with king scallops and their dynamics during cold storage under different modified atmosphere packaging. These different conditions were selected to determine their impact on the microbial communities and their potential inhibiting properties towards spoilage bacteria at temperatures encountered by the consumer during cold food storage. Indeed, practical industrial studies tend to suggest that TVBN content is lower in $\mathrm{CO}_{2}$ rich environments for some seafood products although it can evolve with microbial development.

The first observation was that for every flora considered (except Enterobacteriaceae), the initial counts were relatively high. Indeed, at day D1, depending on the considered medium the counts ranged from $3.04 \log \mathrm{CFU} / \mathrm{g}$ for $\mathrm{H}_{2} \mathrm{~S}$-producing bacteria to $5.5 \log \mathrm{CFU} / \mathrm{g}$ for the total psychrotrophic flora while enterobacteria were at the detection limit with $1 \log$ CFU/g. This could be explained by two facts, first Pecten maximus, like other bivalve molluscs, are filtrating water to feed on plankton; in this context they might concentrate 
microorganisms; secondly, to obtain the meat and coral, the rest of the scallop, including the mantel and the digestive gland, are removed manually which can contribute to the contamination of the eatable parts. Concerning the dynamics of the various populations, the most obvious effect of the tested packaging conditions was the impact of anaerobic conditions, either through vacuum packaging or $\mathrm{CO}_{2} / \mathrm{N}_{2}$ mixtures on pseudomonads. In these conditions, minimum growth potentials $(<\log 0.5 \mathrm{CFU} / \mathrm{g})$ were observed at day D8 while a growth potential of $1.6 \log \mathrm{CFU} / \mathrm{g}$ was observed under aerobic conditions. The impact of $\mathrm{O}_{2}$ depletion, through vacuum or modified atmosphere packaging, on Pseudomonas was not a surprise as most members of this flora are strictly aerobic. The inhibition of Pseudomonas in anaerobic packaging conditions has been reported on different food products (Crowley et al., 2010; Pantazi et al., 2008; Ravi Sankar et al., 2008). Except for day D8, the lowest counts for every studied flora as well as lowest TVBN and TMA contents were observed for the modified atmosphere packaging (MAP) with $>80 \% \mathrm{CO}_{2}$. These results were clearly confirmed by sensory evaluation criteria as only $>80 \% \mathrm{CO} 2$ modified atmosphere samples were acceptable after day D8 (data not shown). Both TVBN and TMA content limits were determined based on all of the results in this study and were considered to be $<30 \mathrm{mg} \mathrm{N} / 100$ $\mathrm{g}$ and $<10 \mathrm{mg} \mathrm{N} / 100 \mathrm{~g}$, respectively. No European regulation exists for TVBN and TMA contents in Pecten maximus scallops, however, EC regulation No 2074/2005 fixed TVBN values at $25-35 \mathrm{mg} \mathrm{N} / 100 \mathrm{~g}$ muscle according to the fish species. Based on the results of this study, the determined TVBN and TMA limits are therefore in accordance with those for fish species.

The microbial diversity of the king scallop ecosystem was assessed by M13-PCR grouping followed by identification of representative isolates by $16 \mathrm{~S}$ rRNA gene sequencing. This approach allowed to show a large biodiversity with at least 26 species identified. Under air, the dominant species corresponded to B. thermosphacta, Pseudomonas spp. and 
Shewanella spp.. These species have been regularly associated with food, and especially seafood products (Fonnesbech Vogel et al., 2005; Hovda et al., 2007; Laursen et al., 2006). Pseudomonas was also the predominant genus along with Moraxella and Vibrio in the scallop Argopecten purpuratus cultured in Chile (Riquelme et al., 1995). The species Moellerella wisconsensis also seemed to be well associated with the king scallop ecosystem as it was the only species identified on VRBG. This species, first described from human stools (HickmanBrenner et al., 1984), has been rarely isolated from food products and its natural reservoir is still unclear (Stock et al., 2003). Interestingly, Matyar (2007) indicated that this species was one of the dominant Gram-negative bacterial species (18\%) in Turkish sea bass; while, Skrodenytė-Arbačiauskienè et al. (2008) identified it in the intestinal flora of freshwater salmon and sea trout. Finally, it was also associated with sea mammals and marine birds (Bogomolni et al., 2008) as well as the sponge Halichondria rugosa (Li, 2009). As a whole, these facts suggest that the marine environment could constitute one of Moellerella wisconsensis main natural reservoirs.

The analysis of the obtained biodiversity data by both culture-dependent and cultureindependent methods allowed to evaluate the impact of the modified atmosphere packaging conditions during storage with a cold chain rupture on the king scallop ecosystem. The results indicated an impact of the packaging conditions on the ecosystem's equilibrium during storage as well as on TVBN and TMA levels. In particular, the MAP with elevated $\mathrm{CO}_{2}$ levels (80 and $100 \% \mathrm{CO}_{2}$ ) allowed for the reduction of the different spoilage bacteria and the nondetection of specific flora (i.e. $P$. haloplanktis). The use of MAP, specifically elevated $\mathrm{CO}_{2}$ levels, has been shown to inhibit normal spoilage bacteria, such as Pseudomonas, Aeromonas and Shewanella spp. in fish and to extend shelf life (Stammen et al., 1990). For scallops, the use of $\mathrm{CO}_{2}$ was shown to extend scallop shelf life (Bremner and Statham, 1987). More recently, Bremer and Fletcher (1999) compared the impact of " $100 \% \mathrm{CO}_{2}$ " MAP and aerobic 
conditions on Pecten alba scallop meat. Under aerobic conditions, the bacterial development was exponential from day 3 and reached $8 \log \mathrm{CFU} / \mathrm{g}$ at day 10 ; while, under " $100 \% \mathrm{CO}_{2}$ " MAP, bacteria only developed from day 7 and reached $6.7 \log \mathrm{CFU} / \mathrm{g}$ at day 28. Moreover, at the end of shelf life a large presence of Gram-positive bacteria corresponding to lactobacilli was observed.

In parallel, a culture-independent method (TTGE) was performed. TTGE and denaturing gradient gel electrophoresis (DGGE) have been previously used to study microbial dynamics of numerous foods including during food fermentations (Ercolini, 2004; Cocolin et al., 2004; Ogier et al., 2004) and more recently rainbow trout fish gut microbiota (Navarette et al., 2012). The obtained patterns have been clustered according to the different packaging atmospheres showing their respective effect on the microbiota composition. Moreover, the TTGE profiles obtained for the high $\mathrm{CO}_{2}$ level packaging seemed to indicate an increase of the bacterial biodiversity. The dominance of the Shewanella spp. and B. thermosphacta was confirmed while the profiles corresponding to Pseudomonas spp. and C. maltaromaticum were not found. On the contrary, two genera, Psychrobacter and Vibrio, non-dominant on the culture media, clearly displayed their respective patterns in the product profiles. These findings emphasize that both methods (culture-dependent and -independent) provide complementary insights into the microbial ecosystem composition of the packaged king scallop meat during storage.

The sensory parameters (appearance and smell of raw king scallops) assessed by an internal panel of six experts and the biochemical spoilage indicator levels (TMA and TVBN obtained by the Conway's Microdiffusion Units - Conway and Byrne, 1936) also indicated that there was an impact by the packaging conditions on these criteria. For example, the scallops packaged with $100 \% \mathrm{CO}_{2}$ presented TMA and TVBN levels representing almost half of the ones observed under aerobic conditions (TMA $30.9 \mathrm{mg} / 100 \mathrm{~g}$ and TVBN $78.2 \mathrm{mg} / 100 \mathrm{~g}$ 
under aerobic conditions vs. TMA $16.3 \mathrm{mg} / 100 \mathrm{~g}$ and TVBN $37.4 \mathrm{mg} / 100 \mathrm{~g}$ under $100 \% \mathrm{CO}_{2}$ ) and were still acceptable from an odour point of view while the declared shelf life of king scallops is 6 days in cold storage. At day D8, all the products were considered spoiled and the results suggested that $B$. thermosphacta, and to a lesser extent Shewanella species, were associated with king scallop spoilage. Pseudomonads could also contribute to spoilage; however, their involvement is less clear as the vacuum packaged scallops as their growth was almost always inhibited ( $89 \%$ of pseudomonads were identified in the other packaging conditions) were already unacceptable from an organoleptic point of view (aspect, texture and smell) at day D4 (no link with TMA and TVBN levels was observed). Interestingly, the scallops packaged at high $\mathrm{CO}_{2}$ levels (80 and 100\%), although unacceptable at day D8 from visual and texture points of view, were acceptable from an odour point of view (data not shown). The potential of packaging conditions for shelf life extension is directly linked to the initial bacterial load. In this study, we showed that the initial microbial load was high (total psychotrophic flora of $5.5 \log \mathrm{CFU} / \mathrm{g}$ ) and therefore, efforts should be done to reduce the initial load to make the most of MAP effects.

Little data is available in the literature on the flora associated with king scallop (Pecten maximus). The results obtained during this study, combining culture-dependent and independent methods, allowed comprehending the complex biodiversity and dynamics of the bacterial flora during cold storage under various packaging conditions.

\section{Acknowledgments}

The authors are grateful to Christelle Fahrasmane and Cécile Desmarais for their technical assistance. This work was funded by OFIMER and the European Fisheries Fund in the framework of the OFIMER project 029/07/C entitled "Connaissance des flores 
d'altération et incidence du mode de conditionnement sur la conservation de la noix de Saint-

Jacques conditionnée » with the industrial contribution of COPEPORT Marée-OPBN.

\section{References}

Altschul, F., Gish, W., Miller, W., Myers, E. W. \& Lipman, D. J. (1990). Basic local alignment search tool. Journal of Molecular Biology, 215, 403-410.

Bogomolni, A.L., Gast, R.J., Ellis, J.C., Dennett, M., Pugliares, K.R., Lentell, B.J. \& Moore, M.J. (2008). Victims or vectors: a survey of marine vertebrate zoonoses from coastal waters of the Northwest Atlantic. Disease of Aquatic Organisms 81, 13-38

Botta, J. R. (1995). Sensory evaluation: freshness quality grading. Evaluation of seafood freshness quality. UK: VCH, 88.

Bremer, P.J. \& Fletcher, G.C. (1998). Applications of modified atmosphere packaging for New Zealand seafoods. The New Zealand Food Journal, 29, 50-55.

Bremner, H.A. \& Statham J.A. (1983). Effect of potassium sorbate on refrigerated storage of vacuum packed scallops. Journal of Food Science, 48, 1042-1047

Bremner, H.A. \& Statham, J.A. (1987). Packaging in $\mathrm{CO}_{2}$ extends shelf-life of scallop. Food Technology in Australia, 39,177-179

Cocolin, L., Rantsiou, K., Iacumin, L., Urso, R., Cantoni, C. \& Comi, G. (2004). Study of the ecology of fresh sausages and characterization of populations of lactic acid bacteria by molecular methods. Applied and Environmental Microbiology, 70, 1883-1894.

Conway, E.J. \& Byrne, A. (1936). An absorption apparatus for the micro-determination of certain volatile substances. The micro-determination of ammonia. Biochemistry Journal, 27, 419-429 
Crowley, K.M., Prendergast, D.M., Sheridan, J.J. \& McDowell, D.A. (2010). The influence of storing beef aerobically or in vacuum packs on the shelf life of mince. Journal of Applied Microbiology, 109, 1319-28

Ercolini, D. (2004) PCR-DGGE fingerprinting: novel strategies for detection of microbes in food. Journal of Microbiological Methods, 56, 297-314.

Edwards, U., Rogall, T., Blacker, H., Emde, M. \& Bottger, E. C. (1989). Isolation and direct complete nucleotide determination of entire genes. Characterization of a gene coding for 16 S ribosomal RNA. Nucleic Acids Research, 17,7843-7853

Ehira, S. \& Uchiyama, H. (1987). Determination of fish freshness using the K value and comments on some other biochemical changes in relation to freshness. In D.E. Kramer and J. Liston (Eds), Seafood quality determination (pp. 185-193). Amsterdam: Elsevier Science B.V.

Fonnesbech Vogel, B., Venkateswaran, K., Satomi, M. \& Gram, L. (2005). Identification of Shewanella baltica as the most important $\mathrm{H}_{2}$ S-producing species during iced storage of Danish marine fish. Applied and Environmental Microbiology, 71, 6689-97.

Guinebretière, M.-H. \& Nguyen-The, C. (2003). Sources of Bacillus cereus contamination in a pasteurized zucchini purée processing line, differentiated by two PCR-based methods. FEMS Microbiology Ecology, 43, 207-215.

Hebbard, C.E., George, J.F. \& Martin, R.E. (1982). Occurrence and significance of trimethylamine oxide and its derivatives in fish and shell-fish. In Martin, RE, George, JF and Ward, DR (Eds), Chemistry and biochemistry of marine products (pp. 149-272). Westport, Conn.: AVI.

Henderson, I., Duggleby, C. J. \& Turnbull, P. C. (1994). Differentiation of Bacillus anthracis from other Bacillus cereus group bacteria with the PCR. International Journal of Systematic Bacteriology, 44, 99-105. 
Hickman-Brenner, F.W., Huntley-Carter, G.P., Saitoh, Y., Steigerwalt, A.G., Farmer, J.J. $3^{\text {rd }}$ \& Brenner, D.J. (1984). Moellerella wisconsensis, a new genus and species of Enterobacteriaceae found in human stool specimens. Journal of Clinical Microbiology, 19,460-3.

Hilts, D.F. \& Dyer, W.J. (1970). Principal acid soluble nucleotides in adductor muscle of the scallop Placopecten magellanicus and their degradation during postmortem storage on ice. Journal of the Fisheries Research Board of Canada, 27, 83-92

Hovda, M.B., Sivertsvik, M., Lunestad, B.T., Lorentzen, G. \& Rosnes, J.T. (2007). Characterisation of the dominant bacterial population in modified atmosphere packaged farmed halibut (Hippoglossus hippoglossus) based on 16S rDNA-DGGE. Food Microbiology, 24, 362-71

Jaffrès, E., Sohier, D., Leroi, F., Pilet, M.F., Prévost, H., Joffraud, J.J. \& Dousset, X. (2009). Study of the bacterial ecosystem in tropical cooked and peeled shrimps using a polyphasic approach. International Journal of Food Microbiology, 131(1), 20-29

Kawashima, K. \& Yamanaka, H. (1992). Effects of storage temperatures on the post-mortem biochemical changes in scallop adductor muscle. Nippon Suisan Gakkaishi, 58, 21752180

Kimura, M., Narita, M., Imamura, T., Ushio, H. \& Yamanaka, H. (2000). High quality control of scallop adductor muscle by different modified atmosphere packaging. Nippon Suisan Gakkaishi, 66, 475-480

Lane, D.J., Pace, B., Olsen, G.J., Stahl, D.A. \& Sogin, M.L. (1985). Rapid determination of 16S ribosomal RNA sequences for phylogenetic analyses. Proceedings of the National Academy of Science, 82, 6955-6959.

Laursen, B.G., Leisner, J.J. \& Dalgaard, P. (2006). Carnobacterium species: effect of metabolic activity and interaction with Brochothrix thermosphacta on sensory 
characteristics of modified atmosphere packed shrimp. Journal of Agricultural and Food Chemistry, 54, 3604-3611.

Li, Z. (2009). Advances in marine microbial symbionts in the china sea and related pharmaceutical metabolites. Marine Drugs, 7, 113-129

Llanos, J., Cid, M., Navarro, S., Dinamarca, A. \& García-Tello, P. (2002). Atypical bacteria accompanying the scallop Argopecten purpuratus. Investigaciones Marinas Valparaiso, $30,57-59$.

Luong, J.H.T., Male, K.B. \& Huynh, M.D. (1991). Applications of polarography for assessment of fish freshness. Journal of Food Science, 56, 335-337, 340.

Matyar, F. (2007). Distribution and antimicrobial multiresistance in Gram-negative bacteria isolated from Turkish sea bass (Dicentrarchus labrax L., 1781) farm. Annals of Microbiology, 57,35-38

Navarette, P, Magne, F., Araneda, C., Fuentes, P., Barros, L., Opazo, R., Espejo, R. \& Romero, J. (2012). PCR-TTGE analysis of $16 \mathrm{~S}$ rRNA from rainbow trout (Oncorhynchus mykiss) gut microbiota reveals host-specific communities of active bacteria. PloS One, 7(2):e31335.

Nicolas, J.L., Corre, S., Gauthier, G., Robert, R. \& Ansquer, D. (1996). Bacterial problems associated with scallop Pecten maximus larval cultures. Diseases of Aquatic Organisms, $27,67-76$.

Ocaño-Higuera, V.M., Maeda-Martínez, A.N., Lugo-Sánchez, M.E. \& Pacheco-Aguilar, R. (2006). The effect of transportation on the physiological condition and free amino acids composition of Nodipecten subnodosus adductor muscle. Journal of Shellfish Research, $25,297-298$.

Ogier, J.C., Lafarge, V., Girard, V., Rault, A., Maladen, V., Gruss, A., Leveau, J.Y. \& Delacroix-Buchet, A. (2004). Molecular fingerprinting of dairy microbial ecosystems 
by use of temporal temperature and denaturing gradient gel electrophoresis. Applied and Environmental Microbiology, 70, 5628-5643.

Ohashi, E., Okamoto, M., Ozawa, A. \& Fujita, T. (1991). Characterization of common squid using several freshness indicators. Journal of Food Science, 56, 161-163, 174.

Olafsdottir, G., Martinsdottir, E., Oehlenschläger, J., Dalgaard, P., Jensen, B., Undeland, I., Mackie, I.M., Henehan, G., Nielsen, J. \& Nilsen, H. (1997). Methods to evaluate fish freshness in research and industry. Trends in Food Science and Technology, 8, 258-265.

Pantazi, D., Papavergou, A., Pournis, N., Kontominas, M.G. \& Savvaidis, I.N. (2008). Shelflife of chilled fresh Mediterranean swordfish (Xiphias gladius) stored under various packaging conditions: microbiological, biochemical and sensory attributes. Food Microbiology, 25, 136-43.

Ravi Sankar, C.N., Lalitha, K.V., Jose, L., Manju, S. \& Gopal, T.K. (2008). Effect of packaging atmosphere on the microbial attributes of pearlspot (Etroplus suratensis Bloch) stored at 0-2 degrees C. Food Microbiology, 25, 518-28.

Riquelme, C., Hayashida, G., Vergara, N., Vasquez, A., Morales, Y. \& Chavez, P. (1995). Bacteriology of the scallop Argopecten purpuratus (Lamarck, 1819) cultured in Chile. Aquaculture, 138, 49-60

Ruiz-Capillas, C., Horner, W.F, Gillyon, A. \& Carol, M. (2001). Effect of packaging on the spoilage of king scallop (Pecten maximus) during chilled storage. European Food Research and Technology, 213, 95-98

Sandaa, R.A., Magnesen, T., Torkildsen, L. \& Bergh, O. (2003). Characterisation of the bacterial community associated with early stages of Great Scallop (Pecten maximus), using Denaturing Gradient Gel Electrophoresis (DGGE). Systematic and Applied Microbiology, 26, 302-311. 
Skrodenytė-Arbačiauskienè, V., Sruoga, A., Butkauskas, D. \& Skrupskelis, K. (2008). Phylogenetic analysis of intestinal bacteria of freshwater salmon Salmo salar and sea trout Salmo trutta trutta and diet. Fisheries Science, 74, 1307-1314

Stammen, K., Gerdes, D. \& Caporaso, F. (1990). Modified atmosphere packaging of seafood. CRC Critical Reviews in Food Science and Nutrition, 29, 301-331

Stock, I., Falsen, E. \& Wiedemann, B. (2003). Moellerella wisconsensis: identification, natural antibiotic susceptibility and its dependency on the medium applied. Diagnostic Microbiology and Infectious Disease, 45, 1-11.

Thomson, A. B., Davis, H. K., Early, J. C. \& Burt, J. R. (1974). Spoilage and spoilage indicators in queen scallops (Chlamys opercularis) held in ice. International Journal of Food Science \& Technology, 9, 381-390.

Torkildsen, L., Lambert, C., Nylund, A., Magnesen, T. \& Bergh, O. (2005). Bacteria associated with early life stages of the great scallop, Pecten maximus: impact on larval survival. Aquaculture International, 13, 575-592.

van Spreekens, K.J.A. (1974). The suitability of a modification of Long and Hammers medium for the enumeration of more fastidious bacteria from fresh fishery products. Archiv fur Lebensmittelhygiene, 25, 213-219. 


\begin{tabular}{|c|c|c|c|c|}
\hline $\begin{array}{l}\text { Strain code } \\
\left(\text { accession } n^{\circ}\right)\end{array}$ & Closest relative & $\begin{array}{l}\% \\
\text { identity }{ }^{1}\end{array}$ & $\begin{array}{l}\text { Genbank } \\
\text { accession } \\
\text { number }\end{array}$ & $\begin{array}{l}\text { Other strain codes associated } \\
\text { to this identification }\end{array}$ \\
\hline D6-MRS-Ga-3 & Actinomyces radicidentis & $98.9 \%$ & AJ251986 & \\
\hline D8-VRBG-Ga-3 & Aeromonas molluscorum & $99.4 \%$ & AY987772 & \\
\hline D8-VRBG-Ga-1 & Aeromonas sp. & $94.2 \%$ & GQ266405 & \\
\hline D1-LH-10 & Arthrobacter bergerei & $100 \%$ & AJ609633 & \\
\hline D4-LH-UV-2 & Brevibacterium antiquum & $98.5 \%$ & AY243344 & \\
\hline D4-LH-UV-6 & Brevibacterium sp. & $98.4 \%$ & FJ652620 & \\
\hline D4-LH-A-3 & Brochothrix thermosphacta & $99.2 \%$ & M58798 & $\begin{array}{l}\text { D4-STAA-UA-2; D6-STAA-UA-2; } \\
\text { D8-STAA-UA-2; D8-STAA-UV-2; } \\
\text { D8-STAA-Ga-1 }\end{array}$ \\
\hline D6-VRBG-UV-2 & Moellerella wisconsensis & $98.5 \%$ & AM040754 & $\begin{array}{l}\text { D8-VRBG-UA-2; D8-VRBG-UV-1; } \\
\text { D8-VRBG-UV-3 }\end{array}$ \\
\hline D8-CFC-UV-4 & Morganella morganii & $98.5 \%$ & DQ513315 & D8-CFC-UA-4 ; D8-IA-Gb-3 \\
\hline D8-LH-Ga-5 & Photobacterium iliopiscarium & $99.4 \%$ & AY849429 & \\
\hline D4-CFC-UA-5 & Pseudoalteromonas haloplanktis & $99.9 \%$ & CR954246 & D6-CFC-Ga-4 \\
\hline D4-CFC-Ga-4 & Pseudomonas fluorescens & $99.9 \%$ & DQ084460 & $\begin{array}{l}\text { D4-LH-Gc-6; D8-CFC-UA-3; D8- } \\
\text { CFC-Gc-3; D4-VRBG-Gc-1 }\end{array}$ \\
\hline D8-CFC-UA-1 & Pseudomonas fragi & $99.8 \%$ & AF094733 & \\
\hline D1-LH-9 & Pseudomonas jessenii & $99.2 \%$ & AM933510 & \\
\hline D6-LH-Gc-5 & Pseudomonas sp. & $99.8 \%$ & EU681009 & D1-CFC-5; D4-CFC-Gc-3 \\
\hline D6-CFC-UV-4 & Pseudomonas syringae & $99.9 \%$ & AJ576247 & \\
\hline D1-LH-3 & Psychrobacter $\mathrm{s}$ & $99.8 \%$ & AB365059 & D6-LH-Ga-3; D8-LH-UA-1 \\
\hline D4-CFC-V-2 & Shewanella baltica & $99.3 \%$ & СР001252 & $\begin{array}{l}\text { D8-LH-UA-5; D4-IA-UA-2; D4-IA- } \\
\text { UV-2; D6-IA-Ga-1 ; D8-IA-UA-2 ; } \\
\text { D8-IA-Gc-2 }\end{array}$ \\
\hline D8-LH-Gb-4 & Shewanella frigidimarina & $99.7 \%$ & AJ300833 & \\
\hline D8-LH-UA-7 & Shewanella putrefaciens & $100 \%$ & AB205575 & $\begin{array}{l}\text { D4-IA-Gc-1; D8-IA-UA-1 ; D8-IA- } \\
\text { UV-3 }\end{array}$ \\
\hline D4-LH-Gb-1 & Staphylococcus cohnii & $99.9 \%$ & AJ717378 & \\
\hline D8-LH-Ga-9 & Staphylococcus pasteuri & $99.9 \%$ & FJ435675 & \\
\hline D8-LH-UV-5 & Staphylococcus sp. & $99.9 \%$ & EU195954 & \\
\hline D8-STAA-UV-3 & Vagococcus salmoninarum & $99.9 \%$ & Y18097 & \\
\hline D8-CFC-Gb-1 & Vibrio sp. & $98.4 \%$ & DQ097524 & \\
\hline D8-LH-UA-6 & Vibrio logei & $99.9 \%$ & AY292932 & D8-LH-UV-3 \\
\hline
\end{tabular}

Table 1. Species biodiversity as observed by the identification of 58 representative isolates. (UA: air, UV: vacuum, Ga: $50 \% \mathrm{CO}_{2} / 50 \% \mathrm{~N}_{2}, \mathrm{~Gb}: 80 \% \mathrm{CO}_{2} / 20 \% \mathrm{~N}_{2}$ and Gc: $100 \% \mathrm{CO}_{2}$ ) 
Table 2. Evolution of TVBN and TMA content in scallops under different packaging

661 conditions. Results are presented in mg N / 100 g scallop meat.

\begin{tabular}{|c|c|c|c|c|c|c|c|c|c|c|}
\hline & \multicolumn{5}{|c|}{ TVBN $\mathrm{mg} \mathrm{N} / 100 \mathrm{~g}$} & \multicolumn{5}{|c|}{ TMA mg N / $100 \mathrm{~g}$} \\
\hline $\begin{array}{l}\text { Time } \\
\text { (days) }\end{array}$ & air & VP & $50 \% \mathrm{CO} 2$ & $80 \% \mathrm{CO} 2$ & $100 \% \mathrm{CO} 2$ & air & VP & $50 \%$ CO2 & $80 \% \mathrm{CO} 2$ & $100 \% \mathrm{CO} 2$ \\
\hline 1 & 3.7 & 3.7 & 3.7 & 3.7 & 3.7 & 3 & 3 & 3 & 3 & 3 \\
\hline 4 & 10 & 10.2 & 8.1 & 8.4 & 7.32 & 1.1 & 1.8 & 3 & 3 & $y$ \\
\hline 6 & 42.2 & 35.9 & 24.3 & 27.7 & 21.7 & 12.2 & 10.6 & 8.6 & 9 & 8.6 \\
\hline 8 & 78.2 & 67.9 & 48.8 & 49.9 & 37.4 & 30.9 & 22.5 & 19 & 21.1 & 16.3 \\
\hline
\end{tabular}

662

663

664

665

666

667

668

669

670

671

672

673

674

675

676

677

678

679 
681

682

685

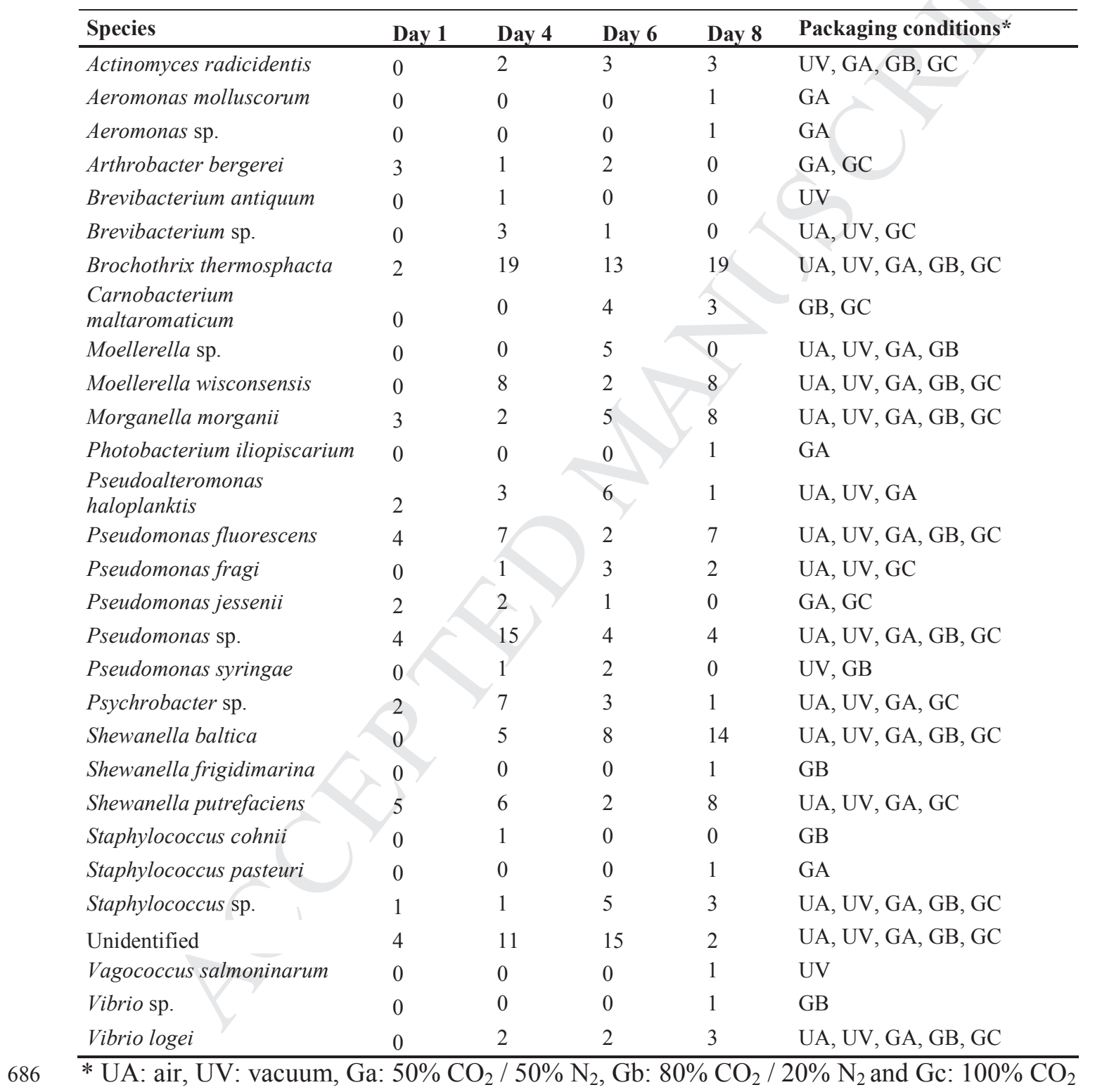

Table 3. Species encountered in scallops under different packaging conditions during cold storage. Results are presented as the number of isolates identified to a given species at each sampling date and according to packaging conditions. For each medium, the square root of the total enumerated bacteria were randomly analyzed. 
689

690

691

692

693

694

695

696

697

698

699

700

701

702

703

\section{Figure legends}

Figure 1. Numeration of bacterial flora associated with king scallop during storage (cold chain rupture $1 / 3$ storage time at $4^{\circ} \mathrm{C}$ and $2 / 3$ at $8^{\circ} \mathrm{C}$ ) under different packaging conditions (air: vacuum: $\square, 50 \% \mathrm{CO}_{2} / 50 \% \mathrm{~N}_{2}: \square, 80 \% \mathrm{CO}_{2} / 20 \% \mathrm{~N}_{2}$ : $\square$ and $100 \% \mathrm{CO}_{2}$ :回) . The following flora were numerated: total aerobic flora (A), enterobacteria (B), Brochothrix thermosphacta (C), lactic acid bacteria (D), pseudomonads (E) and $\mathrm{H}_{2} \mathrm{~S}^{+}$bacteria (F).

Figure 2. Genetic profiles generated by M13-PCR for strains isolated at D8 in the different packaging conditions. The tree was constructed using the Pearson correlation and UPGMA. (UA: air, UV: vacuum, Ga: $50 \% \mathrm{CO}_{2} / 50 \% \mathrm{~N}_{2}$, Gb: $80 \% \mathrm{CO}_{2} / 20 \% \mathrm{~N}_{2}$ and $\mathrm{Gc}: 100 \% \mathrm{CO}_{2}$ )

Figure 3. Proximity dendrogram of the TTGE profiles obtained during storage (D1, 4, 6 and 8) in the different packaging conditions using the Dice coefficient and UPGMA. 
Figure 1

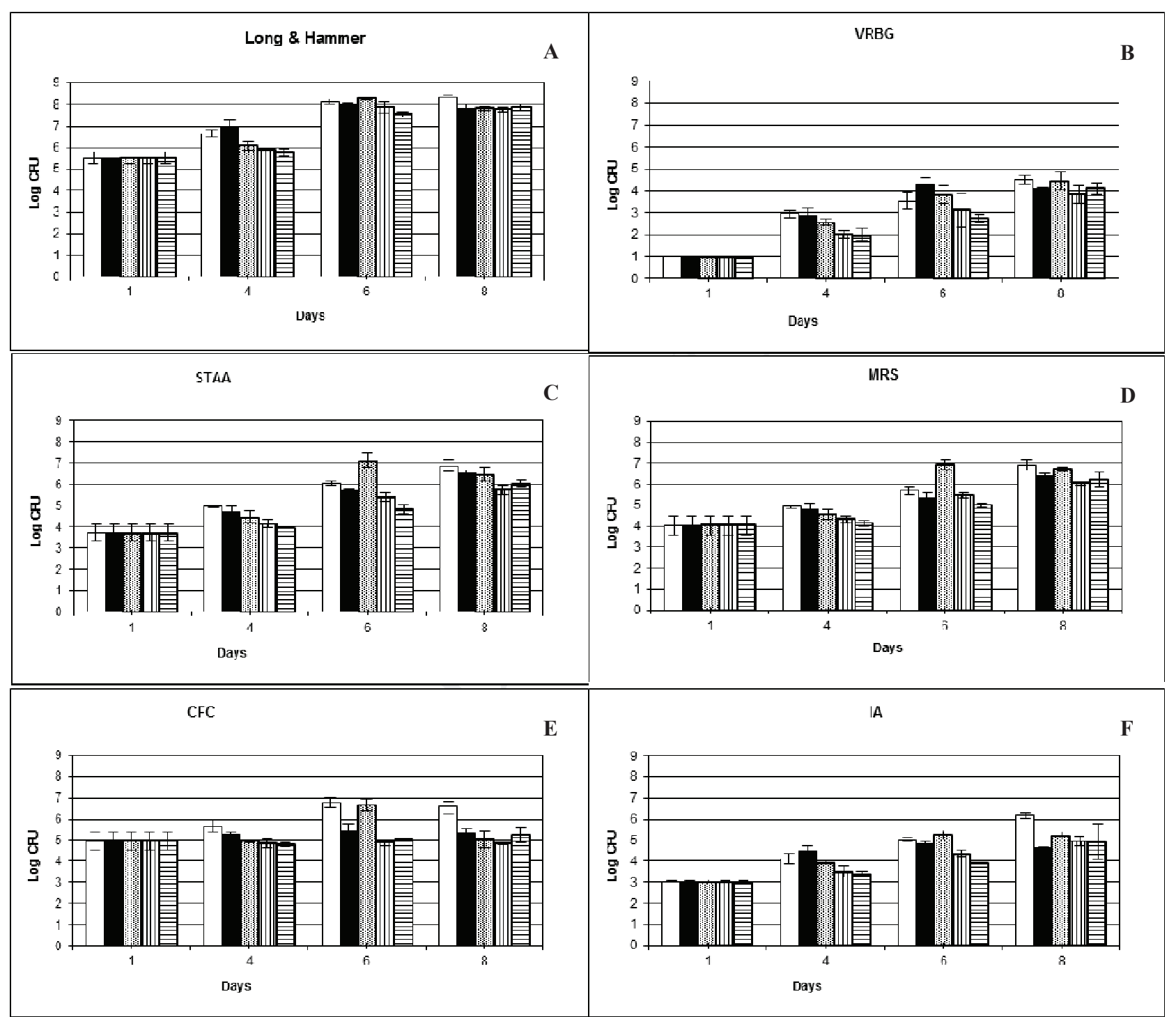


708

709

710

711

712

713

714

715

716

717

718

719

720

721

722

723

724

725

726

727

728

729

730

731

732
Figure 2

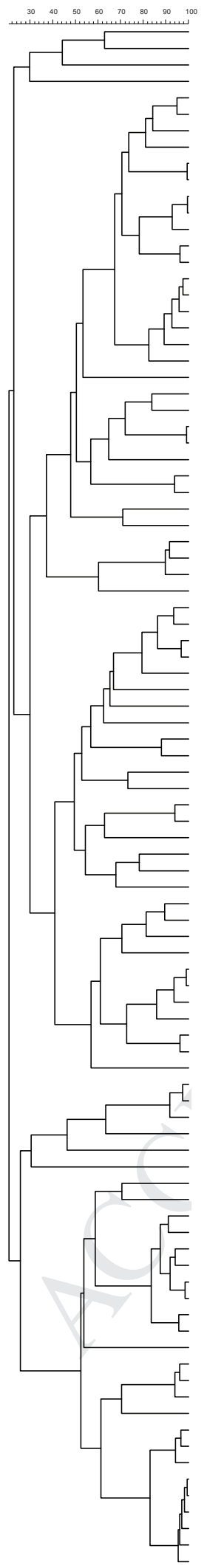

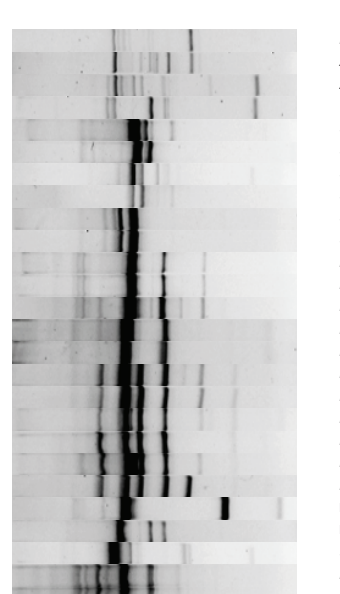

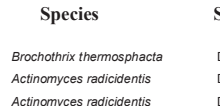

D8-STAA-Gb-3

DE-STAA-UV-3

DB.LH-UA-7

Shewenella putrefacieins $\quad$ D.CFC.Ga-

Shewenella putrefacieins $\quad$ D.LHHGC-3

Shewanella putrefaciens. DP.GF-UA-1

Shewanella putrefacieins. DP.GF-UA-3

Norganella morganii $\quad$ DB-CFC-Ga-2

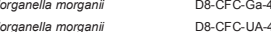

DB.VRBG-UA-1

Moellerella wisconsensis $\quad$ DB-VRBG-UA-2

Moellerella wisconsensis D8-VRBG-UA-3

Mellerler wisconsensis
Moella wisconsensis
DB-VRBG-Gb-1

Moelerella wisconsensis DB-VRBG-SV-3

DE-VRBG-Gb-2

DE-VRBG-SVW
DB-HH-Ga-2

D\&-LH:G-3

$\begin{array}{ll}\text { Shewanella ballica } & \text { D8-LH.GC-2 } \\ \text { Pseudomonas sp. } & \text { DE-VRBGG-Ga-2 }\end{array}$

Aeromonas molluscorum DB-VRBG-Ga-3

Shewanella putrefaciens

Shewanella puteffaciens
Pseudomonas furerscens

De-GF-UV-1

Do-GF-UV-2

DE-VRBG-G6-2

DE-MRS-GC-

Photobacterium iliopiscarium DP-LH-Ga-6

Morganella morganii

Morganella morganii $\quad$ De-LH.G6-1

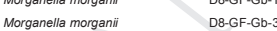

Psvchrobacter ss.

Shewanella ballica DP-GF-UA-2

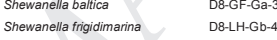

Pseudomonas flucrescens $\quad$ D8-CFC-Gb-2

Psesudomonas flucerscens DP.CFC.GC.

Pseudomonas 5p. DB.CFC.SA-5

Nobric logei

Vibrio logei

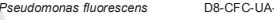

ND DB-GF-Gb-2

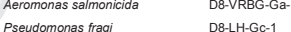

Pseudomonas fragi
Peuddomans sp

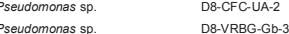

DB-VRBG-G6-3

DSeodomonas ragi

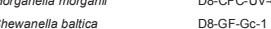

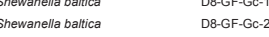

Shewanella ballica D. D.CFC.GC.

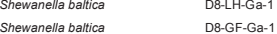

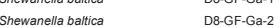

Shewanella batlica

De-LH-UV-2

Staphylococous pasteuri DB-LH-Ga-9

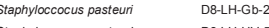

mover

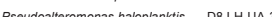

Brochathrix them mosphacta D8-LH-UA-2

Pseudomonas fluorescens $\quad$ DE-VRBG-GC-1

Brochothrix themesphhacta DB-LH-GB-5

Vibriolitioralis $\quad$ DE-CFG-GB-1

Brochothinix themosshacta DE-LH-UV-1

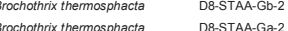

Brochothrix themosposhacta
D.S-STAA-Ga-3

Brochothrix themosphacta DP.STAA-UA-1

Brochothrix themosphacta DPSTAA-UV-1

Vibrio logei DB-LH-UV-3

Shewanella ballica

Shewannella ballica

Shewnenela allica DB.CFC.UV-1

DE-CFC.UV-2

Grochothnix thermosphacta DB-STAA-UA-2

Dochominx themmosphacta D8-STAA-UA

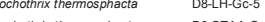

Prochominx themmosphacta DB-STAA-GC-1

Dochomini hermosphacla

Brochothrix themosshacta D D.STAA-Ga-1

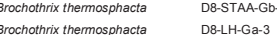

$\begin{array}{ll}\text { Brochothin themosphacta } & \text { D.-LH-Ga-3 } \\ \text { Brochothrix themosphacta } & \text { DE-LH-GC-4 }\end{array}$ 
50

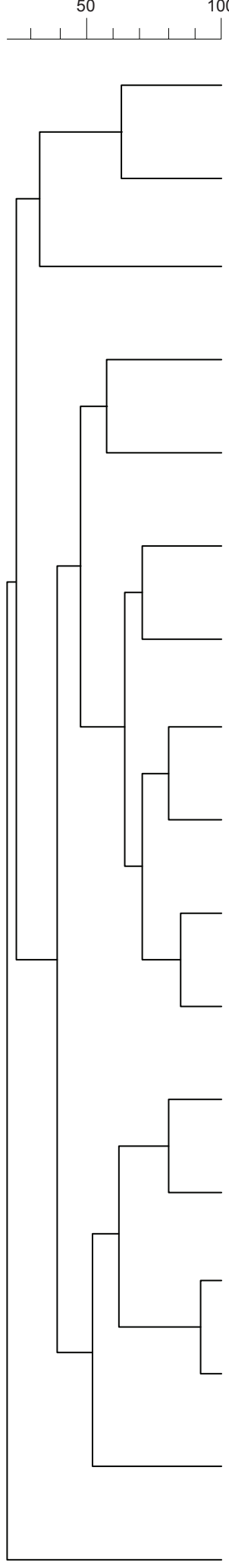

Figure 3

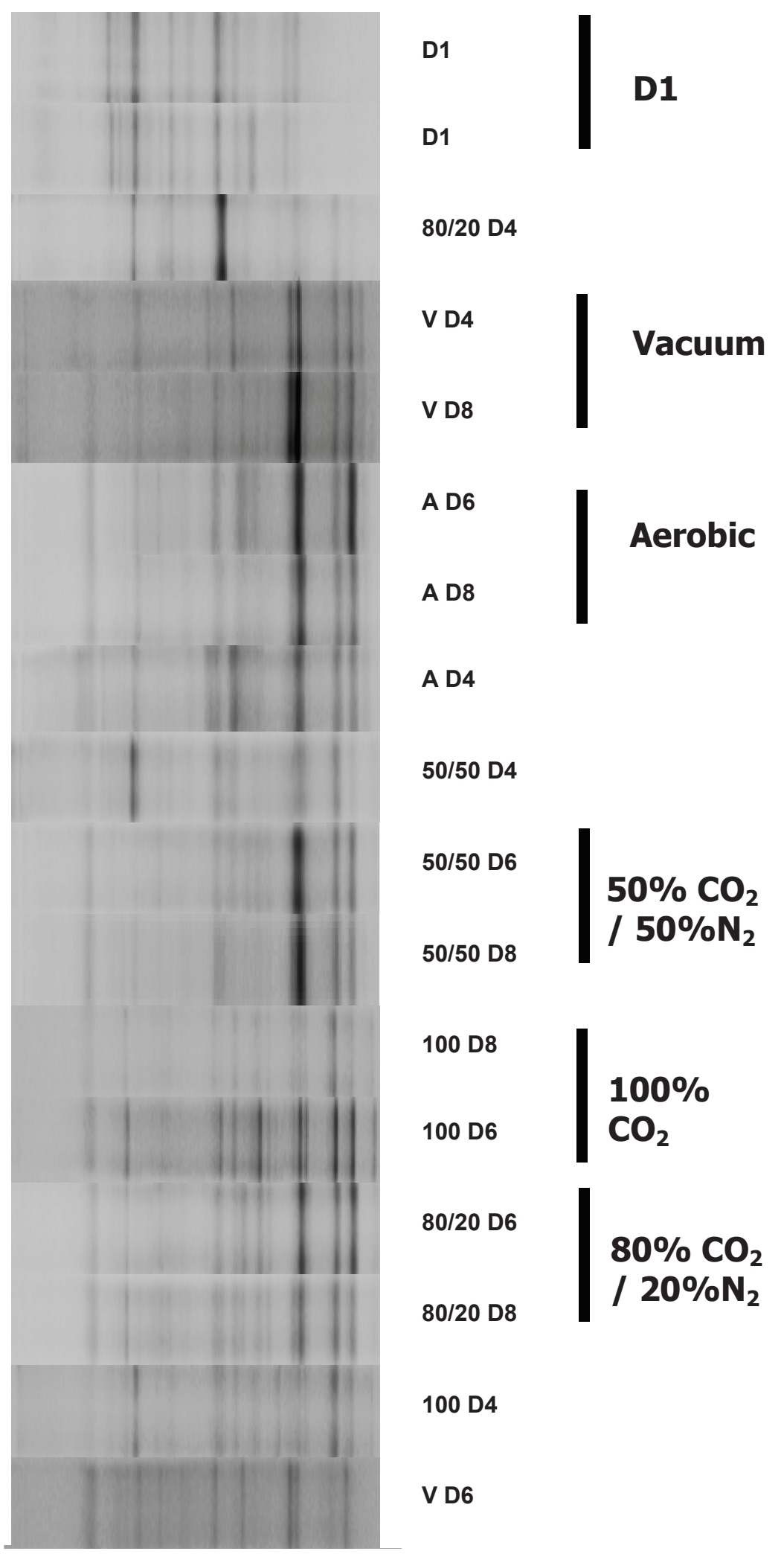

